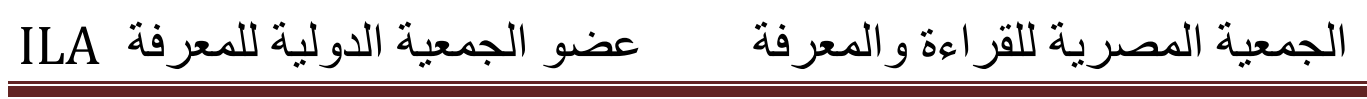

\title{
Using Multisensory Teaching Approach for Developing EFL Prospective Teacher's Immediacy Skills in Classroom \\ Communication
}

\author{
Maha Samir El- Bayaa \\ Assistant Lecturer at Dept. of Curriculum and Instruction (TEFL), \\ Faculty of Education, Port- Said University. \\ Dr. Zeinab Ali EL-Naggar \\ Professor of Curriculum and Methods of Teaching English, Faculty \\ of Education, Ain- Shams University. \\ Dr. Walaa Mohamed EL-Henawy \\ Lecturer of Curriculum and Methods of Teaching English, Faculty of \\ Education, Port- Said University.
}




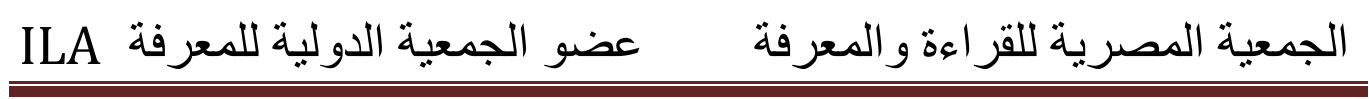




\section{الجمعية المصرية للقراءة والمعرفة عضو الجمعية الدولية للمعرفة ILA}

\section{Abstract}

The present study investigated the effectiveness of using multisensory teaching approach for developing EFL prospective teachers' immediacy skills. The problem of this study was identified in EFL prospective teachers' poor mastery of verbal and nonverbal immediacy skills in practicum classrooms. The study adopted the quasi- experimental design. The subjects of this study were (38) participants, they were selected randomly from fourth year student-teachers (Elementary Education) at Port-Said Faculty of Education. They were divided into two groups (control and experimental). To determine the most required verbal and nonverbal immediacy skills to be developed, a questionnaire containing a list of such skills with their performance sub-skills was designed for TEFL specialists. Based on the selected skills, the researcher designed a pre- post observation checklist of immediacy skills approved by a jury; and EFL prospective teachers of the experimental group were taught to use multisensory teaching to support developing their immediacy skills in the classroom. The results of administering the prepost immediacy skills observation checklist (quantitative instrument), evaluation and self-reflection quizzes, peer assessment checklists, and student- teachers' reflective logs (qualitative instruments) showed that there was a statistically significant difference at 0.01 level between the mean ranks of the control and experimental groups on the postadministration of the observation checklist in favor of the experimental group in both verbal and nonverbal immediacy skills. The findings of the present study revealed that using multisensory teaching approach had a positive effect on developing EFL prospective teachers' verbal and nonverbal immediacy skills.

Keywords: Multisensory Teaching, Immediacy Skills, Instructional Communication, and EFL Prospective Teachers/ Student- teachers. 


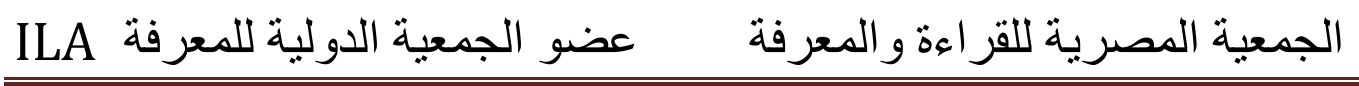

\section{Introduction}

There is a great concern given to English language prospective teacher's preparation programs in the faculties of education. Therefore, researchers and educators usually utilize various skills, techniques and strategies to develop EFL pre-service teachers' preparation programs. However recent studies assure that pre-service teacher education programs remain in need for more development to enable prospective teachers to work effectively.

Malik (2012, p.514) demonstrates that teaching is an activity that is based on interaction between the teacher and the learner. To maximize the benefits of this interaction, it is necessary that the teacher should be proficient in instructional communication skills. EFL prospective teachers need to integrate instructional communication skills to succeed in their profession. They need interpersonal, verbal, and nonverbal communication skills to facilitate the accomplishment of teaching tasks.

Mottet, Richmond, and McCroskey (2006, p.4) reveal that the research in instructional communication has recently become more prominent and dominant for establishing effective and interactive learning environment in the classroom. Therefore, McCroskey, Mottet and Richmond (2006) and Myers (2010), as the beholders of the instructional communication theory, predict that the instructional communication skills would become one of the most effective domains for teachers' preparation in the years to come for fostering students' involvement in learning process.

Valencic, McCroskey and Richmond (2005, p.1) point out that there are three essential components of instruction: course content, pedagogy, and instructional communication. Akers and Johnson (2006, p.1) define instructional communication as the study of communication in the classroom. This entails teacher characteristics (e.g. immediacy and clarity), student characteristics (e.g. learning styles), instructional 


\section{الجمعية المصرية للقراءة والمعرفة عضو الجمعية الدولية للمعرفة ILA}

methods, the pedagogy of communication in general, and teacher- student relationships.

Mottet, Richmond, and McCroskey (2006, p.4, 283) add that examining the instructional communication phenomenon might include a number of variables that fall into one of three clusters: teaching, learning, and communication. In the teaching cluster, the variable might include teacher self- efficacy, teaching satisfaction, and motivation to teach. In the learning cluster, the variable might include student learning compliance, and motivation. In the communication cluster, the variable might include teacher and students use of verbal and nonverbal message, such as verbal and nonverbal immediacy, affinity- seeking, humor, clarity, and compliance gaining strategies. They add that the rhetorical instructional research variables include teacher credibility, task attractiveness, clarity, and humor. While, research variables that have relational communication applications include immediacy, affinityseeking, confirmation, and behavioral alternation techniques.

Both teachers and students communicate throughout their senses. Senses are the channels of communication messages. According to Moustafa (1999, p.2), activating different senses would be a value-added factor to the effectiveness of communication among the different parties and elements of teaching environment. So, there is a need for adopting teaching strategies which are based multi- sensory teaching approach being of relevance to learning styles theories; which have been found to be effective in developing strategies to teach diverse learners in the classroom.

EL-Fatihi (2006, p.5) declares the components of verbal and nonverbal communication used within the classroom seem to be closely related to multisensory teaching approach. When designing learning activities that integrate the multisensory learning styles of the students (visual- auditory- kinesthetic), this can lead to better and effective communication between the teacher and students in the teaching- learning 


\section{الجمعية المصرية للقراءة والمعرفة عضو الجمعية الدولية للمعرفة ILA}

process in the classroom, and will help students feel relaxed, receptive, motivated and open- minded to learning. EFL teachers need to base instruction on their students' learning styles.

Azmi (2013, p.33) explores that both communication and multisensory teaching seem to share a common ground. Effective communication process- in general and instructional communication- in particular involve variety of senses. Communication depends on senses which are the core of multisensory teaching in the classroom. Thus, all students can benefit from multisensory teaching; as every student processes information differently. This teaching method allows each student to use a variety of their senses to understand and process information. Hence, the EFL prospective teachers will have more participation, self- confidence, motivation, and interaction that they can effectively communicate with all different learning styles and types of students.

Therefore, the present study tried to advocate EFL prospective teachers' need to develop their instructional communication in the classroom throughout their verbal and nonverbal immediacy skills not only as a means for controlling and facilitating classroom activities, but also as an integral part of the course content and input materials based on multisensory teaching approach in order to continue the pathway of improving EFL prospective teachers' performance in the classroom.

\subsection{Background}

\section{Immediacy Skills:}

According to Johnson and McCroskey (2004, p.61), Saechou (2005, p.15); Faylor, Beebe, Houser, and Mottet (2008, p.147); Shu-Fang and Aust (2008, p.481); immediacy consists of the teacher's nonverbal and verbal communication behaviors. Immediacy verbal behaviors (e.g., using humor or personal examples, praising student work, getting 


\section{الجمعية المصرية للقراءة والمعرفة عضو الجمعية الدولية للمعرفة ILA}

feedback, and even calling students by name) and the nonverbal immediacy (e.g., eye contact, smiling, and positive head nods). Both teachers' nonverbal and verbal immediacy skills have shown to have a positive influence on students' learning. Teachers might be immediate for a number of reasons: to show concern for students' needs, to initiate communication with students, or even to take control of a classroom situation in order to achieve a goal. Teachers who engage in immediate verbal and nonverbal skills have potentially more influence over students, an influence that may aid those teachers in accomplishing their goals; as verbal and nonverbal immediacy tends to evoke more communication and liking from their students.

Valencic, McCroskey, and Richmond (2005, p.1) refer to nonverbal immediacy as behaviors that would enhance closeness to and nonverbal interaction with students. These behaviors included moving around the room while teaching, making eye contact while talking, and using gestures while talking to students, using appropriate touch, having a relaxed body position while talking, using a variety of vocal expressions, smiling, nodding, maintaining eye contact, spending time with students, and dressing appropriately.

Mottet, Richmond, and McCroskey (2006, pp.283-300); Wrench, Richmond, and Gorhann (2009, p.15); and McCroskey, Teven, Minielli, and McCroskey (2014, p.283) illustrate that teacher's immediacy is one of the most researched instructional communication variables. Within the instructional context, immediacy is the degree of perceived physical and psychological closeness between teachers and students. Immediacy represents sets of verbal and nonverbal communication behaviors that indicate the teacher's willingness to approach and be approached by students and is influential in reducing the perceived physical and psychological distance between them. Such closeness, either literal or psychological, has a major effect on the perceived quality of a communication relationship. Perceptions of immediacy expressed through 


\section{الجمعية المصرية للقراءة والمعرفة عضو الجمعية الدولية للمعرفة ILA}

behaviors such as forward body leans, head nods, eye contact, demonstrating variety in vocal pitch, loudness, and tempo; smiling; leaning toward a person; face- to- face body position; decreasing physical barriers (such as podium or a desk ) between teachers and their students, overall relaxed body movements and positions, the teachers' use of humor, praise, action or comments, using inclusive pronouns (we, us ,our), provide feedback, and asking students about their perceptions about assignments that indicate willingness to converse with students both in and out the classroom.

They add if teachers use effective nonverbal and verbal behaviors with their students to increase perceptions of immediacy, their students will feel closer to them. Thus, there will be a meaningful and positive relationship between verbal and nonverbal immediacy and cognitive as well as affective learning. Teachers who use immediacy skills result in students who have overall a more positive attitude toward the instructor and the course content. The verbal immediacy scale (VIS) is an assessment instrument to assess teacher's verbal immediacy skills. The nonverbal immediacy scale (NIS) is an assessment instrument to assess teacher's nonverbal immediacy skills.

Witt, Wheeless, and Allen (2004, pp.184- 207), and Richmond, Lane, and McCroskey (2006, pp.167-194) report some of the most important findings for teacher's immediacy:

- Teacher verbal and nonverbal immediacy increases student cognitive learning. Teachers' use of immediacy behaviors helps their students learn.

- Teacher verbal and nonverbal immediacy increases student affective learning. Students have more positive feelings about both the teacher and the course content.

- Teacher verbal and nonverbal immediacy is significantly and positively related to perceptions of teacher clarity. Teachers who 


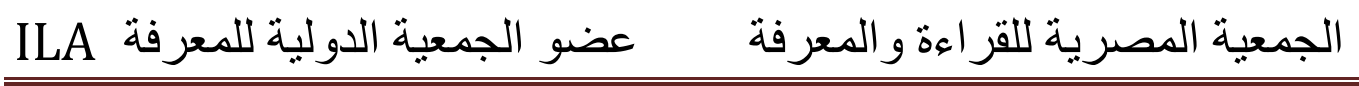

are immediate are perceived as providing more clear instruction than teachers who are not immediate.

- Teacher nonverbal immediacy increases students' perceptions of teacher effectiveness.

- Teacher nonverbal immediacy plays a mediating role in the reception and effectiveness of teacher control strategies.

- Teacher immediacy produces a reciprocal liking among teachers and students.

To sum up, EFL teachers should be aware that using verbal and nonverbal immediacy skills can effectively and powerfully improve their instructional communication and teaching in the classroom, and enhance their students' learning of English. Therefore, EFL teachers should be more sensitive in their English classrooms, knowing that their immediacy skills can have a positive influence reducing students' anxiety in English learning, and result in more effective learning outcomes.

\section{Multisensory Teaching Approach:}

Spinelli (1998, pp.3-4, pp.13- 19) declares that with the increasing numbers of students with diverse needs included in general education; the preparation of pre-service teachers needs to be reformed. Traditional curriculum, methods and management courses need to be revised as the population in general education classes is changing. Pre- service teachers need to be able to adapt standard teaching techniques, modify standard materials and curriculum and adjust standard classroom management techniques in order to effectively teach students with diverse needs. In order to be adequately prepared for this diverse population of students, pre-service teachers need to be familiar with a variety of teaching skills and alternate assessment measures required to provide all students with the curricular and program modifications they need. Therefore, teacher educators have to demonstrate more interactive teaching methodology and performance skills that are both multidimensional and multisensory through demonstration, simulation, role playing, cooperative group 


\section{الجمعية المصرية للقراءة والمعرفة عضو الجمعية الدولية للمعرفة ILA}

activities, and providing learning environments where instructional communication is encouraged and facilitated, feedback is immediate and detailed, and where learning becomes a collaborative and social experience.

Moreover, Spinelli adds that pre-service teachers need to develop effective instructional communication skills which include skills such as, teacher's verbal and nonverbal immediacy, teacher's clarity, credibility and task attractiveness, and seeking affinity, in order to deal effectively with their students. Thus, for developing competence and confidence in these pertinent skills, teacher educators have to model the procedures of these skills in their college classrooms. They will be expected to design and implement authentic learning and assessment procedures, and model ways that teachers can involve all students in varied, multisensory and interactive activities which will directly impact on them and help them have excellent instructional communication skills. Therefore, the next generation of pre-service teachers needs to know how to make learning more relevant, interesting and meaningful to meet the varying needs of a more diverse population of students.

Denny (2001, pp.13-14), and Bedard (2002, pp.4- 10) point out that students' instructional needs lay in the ways in which students process information throughout the five major senses (visual, kinesthetic, auditory, taste, and smell). Most educational researchers usually concentrate on the three major communication areas- the visual, kinesthetic, and auditory senses. It is important to accept that most students use all three. However; students are different, that some will use one sense more predominate than the other two. Thus, it is important for teachers to be aware of how they communicate information to their students; and whether the predominant sense visual, kinesthetic or auditory. In order to succeed as a communicator, teachers need to have a great understanding of their students' styles of receiving information. 


\section{ILA الجمعية المصرية للقراءة والمعرفة عضو الجمعية الدولية للمعرفة}

Henry (2008, p.1), and Wrighton (2010, p.1) recommend the principle of combining movement with speech and reading be applied at other levels of language learning as well. Students may learn hand gestures to help them memorize the definition of a word. Students may manipulate word cards to create sentences or classify the words in sentences by physically moving them into categories. They might move sentences around to make paragraphs. The elements of a story may be taught with reference to a three-dimensional, tactile aid. In all, the hand, body, and movement are used to support comprehension and production of language. Therefore, multi-sensory teaching can develop both EFL teachers' and students' verbal and nonverbal communication skills.

Rains, Kelly, and Durham (2008, p.248) assert that multi-sensory teaching techniques have proven to be helpful in the development of a foreign language. Drills that contain visual, auditory, and even tactile involvement by students improve their comprehension of the foreign language. Multi-sensory techniques are very helpful when employed in primary and adult ESL classrooms. Teachers must employ activities that involve many, if not all, the senses in order to teach students to communicate in foreign language.

Therefore, Price (2010, p.1) illustrates that all of students learn and communicate through all their senses. Therefore, teachers have to try to involve all the senses from time to time. Some examples:

Sight: through texts, pictures, graphics.

Sound: through listening to teacher, to recordings, videos; talking, singing, rhymes, story-telling, clapping rhythmically to indicate syllabic stress, etc.

Touch: handling objects, making things, describing shapes, gesturing, using computer keyboard, etc.

Taste: sampling food and drink, savoring the language (articulation, intonation) 


\section{الجمعية المصرية للقر اءة والمعرفة عضو الجمعية الدولية للمعرفة ILA}

Action: manual and physical activity, games involving manipulating objects or moving about.

Furthermore, Flazon, Calleja, and Muscat (2011, p.53), and Brailey and Stowe (2013, p.1) are of the opinion that multisensory structured language education of basic language skills provides instruction that is explicit, systematic, and sequential. The structure of the instruction provides the power, and the multisensory approach promotes active student engagement to enhance learning and teach the basic language skills thus supporting the structured approach to language instruction. Teachers can use multisensory learning for instruction within the general education classrooms for all students. This technique is simply a teaching strategy which seeks to actively stimulate all available senses simultaneously within a structure and using linguistic knowledge.

The following figure summarizes the relationship between instructional communication skills and multisensory teaching approach:

Figure 1. Relationships between Multisensory Teaching and Instructional Communication.

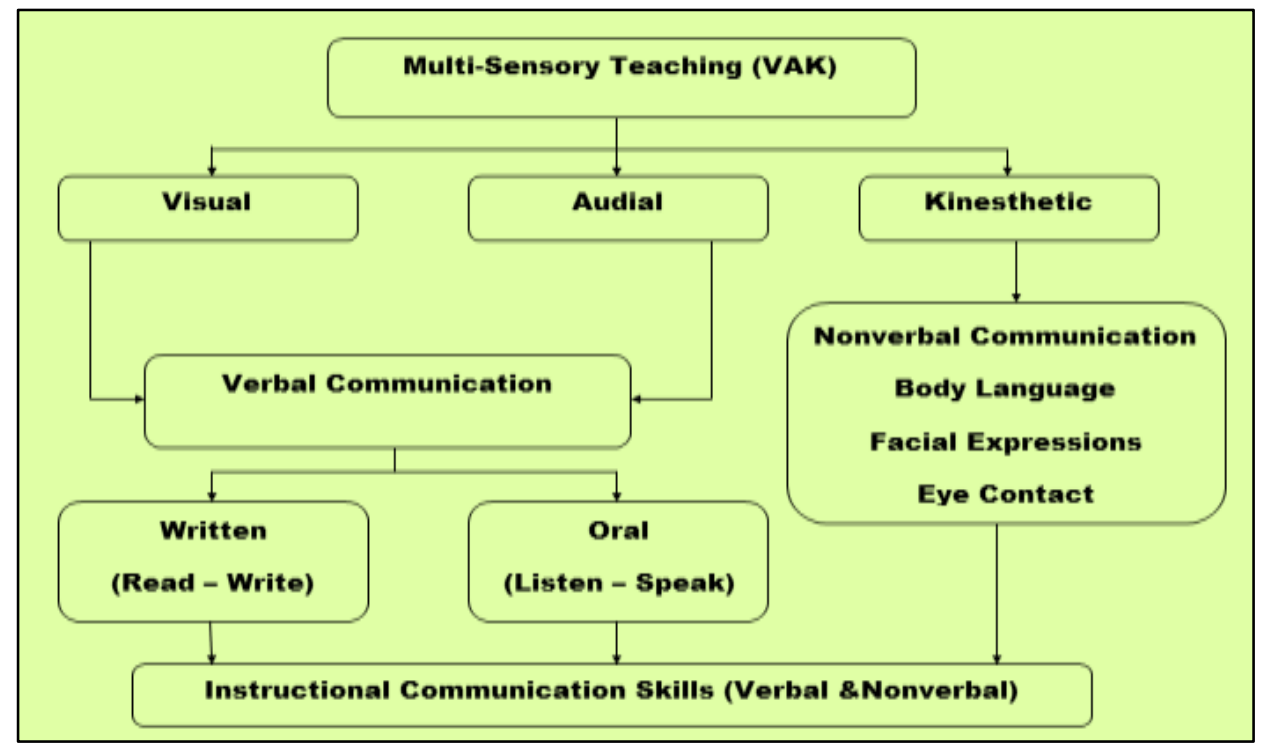




\section{الجمعية المصرية للقر اعة والمعرفة عضو الجمعية الدولية للمعرفة ILA}

Source: (Original, 2018).

As shown in the above figure, multisensory teaching (VAK) includes visual, auditory, and kinesthetic teaching techniques which are represented by verbal and nonverbal messages between the teachers and their students. Instructional communication also contain teachers' performance of verbal and nonverbal immediacy skills that help the EFL teachers improve their performance in the teaching process and satisfy different students' learning styles in the classroom in order to promote the students' cognitive, affective, and behavioral learning.

In conclusion; incorporating multi- sensory delivery in language teaching will give students a large number of benefits to broaden their opportunities in successfully acquiring a foreign language. These advantages include enhancing motivation, promoting autonomous learning, fostering critical thinking skills, encouraging innovation, establishing interaction, boosting communication, and optimizing cooperative learning. Furthermore, if teachers use effective verbal and nonverbal behaviors with their students to increase perceptions of immediacy, their students will feel closer to them. Thus, there will be a meaningful and positive relationship between verbal and nonverbal immediacy and cognitive as well as affective and behavioral learning throughout using the multi-sensory teaching approach.

\subsection{Context of the Problem}

While supervising EFL prospective teachers in the practicum, the researcher has observed that they suffer apparent problems in communicating their ideas and emotions clearly to their pupils either verbally or nonverbally, monitoring learning activities, giving constant supportive feedback, providing a welcoming, friendly and interactive learning environment in the classroom. They also lack both adequate knowledge and understanding the importance of the instructional communication and using verbal and nonverbal immediacy skills inside 
the classroom. It was also observed that the pupils do not interact properly with the EFL prospective teacher and almost look bored, less motivated, more passive, and hardly volunteered to share activities or ideas. This indicates that EFL prospective teachers suffer inefficiency in their verbal and nonverbal immediacy skills.

For more empirical evidences, the researcher conducted a pilot study. She prepared a checklist to evaluate the initial verbal and nonverbal immediacy skills of (26) EFL prospective teachers. The obtained findings seem to indicate the apparent inefficiency of the observed immediacy skills of EFL prospective teachers (according to the low scores in the pilot study).

The problem of the present study is also supported by reviewing previous studies handling the EFL teachers' weakness in verbal and nonverbal immediacy skills such as Johnson and McCroskey (2004), Saechou (2005), Tabasco (2007), Faylor, Beebe, Houser and Mottet (2008), Shu-Fang and Aust (2008), Velez and Cano (2008), Baker (2010), Ozmen (2011), Hughes (2014), and Guerrero (2017). These studies indicated that immediacy skills are neglected in EFL classrooms.The findings of these studies indicated the importance of improving teachers' immediacy skills. However, the researcher of the present study noticed that when exploring the related literature, she hardly encountered previous studies of direct relevance to the development of Egyptian EFL teachers' verbal and nonverbal immediacy skills. That is why the researcher believes that verbal and nonverbal immediacy is one of the neglected areas of teacher training/ preparation - despite its importance for successful teaching.

Thus, the lack of research in this field justifies the need for manipulating further studies in order to develop EFL prospective teacher's immediacy skills. Therefore, the present study is examining the effectiveness of multisensory teaching approach in developing EFL prospective teachers' immediacy skills. 


\subsection{Statement of the Problem and Research Questions}

The problem of the present study is that EFL prospective teachers have poor mastery of the verbal and nonverbal immediacy skills that may be due to their insufficiency in the existing preparation program. Therefore, the present study sought to find answers to the following main question:

What is the effectiveness of multi-sensory teaching approach in developing EFL prospective teachers' immediacy skills?

The above main question was investigated through the following subquestions:

1. What are the verbal and nonverbal immediacy skills required for EFL prospective teachers?

2. To what extent do EFL prospective teachers demonstrate these skills?

3. To what extent can multisensory teaching approach be effective in developing EFL prospective teachers' immediacy skills?

\section{Review of Literature}

\section{Teacher's Immediacy:}

For many years, teacher's immediacy is the focus of a great deal of instructional communication research. In order for teachers to communicate effectively, teachers need to develop their verbal and nonverbal immediacy skills. Many studies have found that teacher's immediacy has a positive impact on students' learning. Mottet, Richmond and McCroskey (2006, p.284) assert that teacher immediacy increases students' learning and is associated with a decrease in students' learning loss; teachers would benefit from attempting to incorporate more immediate communication skills into their instruction to increase their students' affective, cognitive, and behavioral learning. 


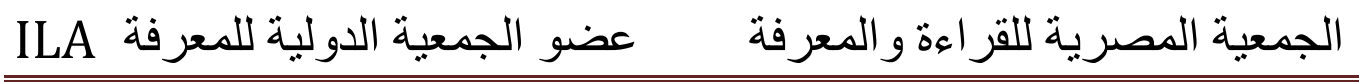

Kerssen- Griep (1997) investigated the role of instructional communication in students' motivation to learn. The study extended previous communication research on motivation, immediacy, and power in the classroom. The participants in the study were 45 graduate students and 2 university professors. 30 students were enrolled in Pacific Northwest University School of Nursing and 15 were pursuing their Master of Arts in Teaching at Vashon University. The results of the study reported that instructional communication encouraged students' ownership of learning, maintained a climate safe for independent thought and risk- taking, expressed respectful interest in students' classroom contributions, encouraged application, analysis, synthesis, and evaluation of course knowledge, encouraged and respected autonomous thought, encouraged student self- respect for their own experiences.

Macgregor (2001) investigated the verbal and nonverbal communication skills of the college teacher such as affiliation, behavioral alteration techniques, discourse style, teachers' use of language, teacher immediacy, and clarity. Participants include lecturers $(n=5)$ and teaching assistants $(n=5)$ and professors $(n=4)$, years of teaching covered a wide range. Different learning styles of students in their classes included. Results recommend guidelines for improving teachers' instructional communication skills.

Ginsberg's research (2004) attempted to identify faculty characteristics that were associated with the instructional communication characteristics of immediacy and clarity. It sought to identify how and why college faculty members develop immediacy and clarity. This study was conducted at two public, comprehensive colleges and universities. A group of 11 teachers were chosen. The findings asserted that the students of highly immediate and clear university teachers reported improved learning and motivation.

Mathis (2006) stated that teaching and training share many characteristics. He explored constructs of instructional communication of the trainers that impact trainees' motivation and delivery of learning, 


\section{الجمعية المصرية للقر اءة والمعرفة عضو الجمعية الدولية للمعرفة ILA}

Mathis mentioned four areas of appropriate instructional communication behaviors: clarity; enthusiasm; interaction; and verbal and nonverbal immediacy which have improved trainees' motivation, delivery of learning, and achieved learning outcomes. He illustrated how motivation and immediacy, and effective instructional behaviors (clarity, enthusiasm, and interaction) have been shown to increase cognitive, affective, and behavior learning and transfer of learning. There was a positive correlation between both teacher verbal and nonverbal immediacy and motivation and learning.

Tabasco (2007) studied the relationships between teachers' immediacy, creativity, and students perceived learning at the secondary level. Data was collected from a suburban high school in the Mid-Atlantic area with 304 students and 16 teachers participating. The results of this study showed that the more flexible and fluent a teacher, the more nonverbal immediacy the students felt from that teacher. Students perceived learning scores were significant when analyzed with creativity and with nonverbal immediacy. Research independently supported teacher's immediacy and creativity impacting various levels of learning.

Mottet, Garza, Beebe, Houser, Jurrells, and Furler (2008) examined how students' perceptions of their teachers' instructional communication behaviors (nonverbal immediacy, clarity, content relevance, and teacher confirmation) were related to their affective learning in math and science. A survey was used to collect perceptions from 497 ninth-grade students. Results indicated that Teacher nonverbal immediacy, clarity, confirmation and content relevance behaviors are positively related with students' math/science affective learning outcomes.

Hsu (2010) investigated teachers' nonverbal immediacy behaviors in relation to students' motivation for learning English. A sample of 303 participants was drawn from a technology institution in central Taiwan. The results of the Pearson correlation indicated that teachers' nonverbal immediacy behaviors were correlated positively and significantly with students' motivation for learning English and willingness to talk. 


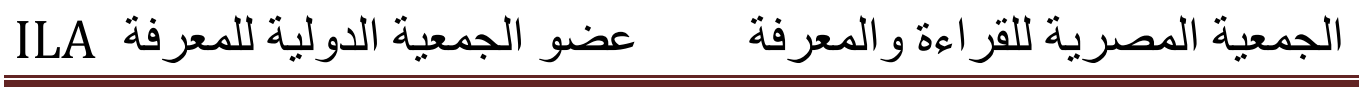

Asiri (2013) conducted a quasi-experimental study to investigate the effects of instructor's verbal and nonverbal immediacy skills on students' communication (i.e., class participation) and learning outcomes (i.e., state motivation, communication satisfaction, affective learning, and cognitive learning). The study sampled 115 undergraduate students at King Khalid University in Saudi Arabia. The participants were distributed into three groups: two control groups and one treatment group. The findings of this study strengthened that generally, instructor verbal and nonverbal immediacy skills cause positive student communication and learning outcomes. Instructor's immediacy appeared to be a significant factor in developing interpersonal relationships with students and promoting student communication and learning outcomes.

Winters' research (2014) recognized the importance of instructional communication between students and faculty instructor in the classroom environment. Nonverbal immediacy, confirmation, and caring were explored as instructional communication behaviors that influence undergraduate college classrooms. The sample consisted of eight undergraduate students at fourth year university in Northern California. Results showed that instructors exhibiting a friendly mood, showing happiness, approachability, and flexibility are more likely to create a positive communication climate, and that the lack of verbal and nonverbal instructor communication reflecting the lack of desire to interact with students led to a more negative and defensive communication climate.

Finally, Guerrero (2017) examined the impact of engineering instructors' use of immediacy skills on engineering students' motivation. The sample was limited to (139) undergraduate students in engineering classes enrolled at a mid-sized, Midwestern public university. The results revealed that when students perceived their instructors as helpful, students' motivation to learn and ask more questions increased. These findings present valuable insight for educators on how their immediacy skills can both positively affect student motivation and possible retention. 


\section{الجمعية المصرية للقراءة والمعرفة عضو الجمعية الدولية للمعرفة ILA}

The study established a direct and positive relationship between the use of immediacy and increased student performance.

In this research immediacy means the degree of perceived physical and psychological closeness between teachers and students. Immediacy represents sets of verbal and nonverbal communication skills that indicate a teacher's willingness to approach and be approached by students and is influential in reducing the perceived physical and psychological distance between the teacher and his/ her students. Aspects of nonverbal immediacy are: physical proximity, body language, eye contact, gestures, postures, vocal expressiveness, and smiling; while aspects of verbal immediacy include encouragement, instructional humoring, monitoring discussion, and timely feedback.

\section{Multisensory Teaching Approach:}

There are many previous studies which prove the effectiveness of multi-sensory teaching approach in developing the EFL students' learning and communication.

Homer (2007) investigated the effectiveness of multisensory environments (MSE including visual and motor activities) in promoting interaction and developing communication skills (such as: use signs, gesture, sounds, touch, facial expression, vocalization, looking at objects, looking away from objects) in pupils with profound and multiple learning difficulties. The study used a two-stage design to collect qualitative data. A questionnaire for staff was sent out to special schools across London and the South East. Observations of children in the MSE and in the classroom were then carried out at three of the schools. The two-stage design allowed comparisons to be drawn between staff views of the use of the MSE and the researcher's own observations. The study concluded that MSE is used for specific communication goals and it also encouraged communication between the teachers and the pupils. 


\section{الجمعية المصرية للقر اعة والمعرفة عضو الجمعية الدولية للمعرفة ILA}

Bitter (2011) investigated the effectiveness of explicit, multisensory, structured language arts instruction, compared to conventional reading instruction. Five Arizona experimental and six control schools with an average of 1,000 general education kindergarten through third-grade students participated. In the study, experimental group students showed higher mean values on each administration of measures demonstrating an average medium effect (0.54) on student achievement. A possible explanation is that the experimental program integrated explicit, multisensory, structured language arts instruction with research-based components of skilled reading.

Flazon, Calleja, and Muscat (2011) investigated the effectiveness of a structured multisensory program on early literacy (writing and reading). The study was implemented in a Maltese private school. The data were collected through a questionnaire given to all nine teachers working with the early years of the school. This study confirmed that the structured multisensory techniques are inclusive strategies and respectful of the learners' individual learning preference. Results showed that the use of structured multisensory techniques for teaching literacy is one of the best ways to introduce and develop literacy in the classroom.

Stoffers (2011) examined how multisensory education impacted learning and community in a second grade general education classroom in New-Jersey. The participants were twenty-three students, fourteen students were male and nine students were female. Lesson plans that targeted multiple senses were developed and implemented in the classroom. Results revealed that multisensory education can lead to student motivation and engagement, as well as provide a generative space for the use of technology and making connections to the outside world. Multisensory education also helped teachers to access students' needs and aid in fostering a positive classroom environment. Finally, using a teaching approach that targets the students' senses promotes the development of a student-centered classroom and encourages students who had been silent within traditional classroom settings. Thus, teaching 


\section{الجمعية المصرية للقراءة والمعرفة عضو الجمعية الدولية للمعرفة ILA}

through multisensory methods has enormous implications for new teachers who are seeking ways to actively and meaningfully engage students within the classroom.

Azmi (2013) investigated the impact of multi- sensory delivery- the multimedia environment of the internet (e.g. text, image, sound, and video) - on students' English language learning in Morocco. Ten Moroccan English language students participated. According to the findings, multi- sensory delivery in the English language classroom has generated improvements in students' language skills, increased their interest in learning and ensured a more interactive and varied learning in the classroom.

Jasmine and Connolly (2015) conducted a study to determine if multisensory activities enhanced spelling accuracy on weekly tests. Through different activities that involved multiple senses, weekly pre and posttests, observational checklists, and open-ended questionnaires were used to triangulate data. This study was conducted in a school district located in an upper/middle class. The participants were 22 second grade students. The results of this data suggested that using multisensory activities may have helped to improve student spelling accuracy as students conveyed that they enjoyed using multisensory activities and welcomed their continued use.

Recently, Alwaqassi (2017) investigated how teachers use a multisensory learning approach in special education classes in three schools in Indiana. The data, which came from three teachers in three different schools, was collected via observation and interview. The findings showed that teachers had different understanding of the meaning of multisensory approach to teaching and differing ways of applying it. In addition, all of the teachers agreed that students with disabilities benefit from the multisensory approach of teaching, as the students got more engage and progress with the lessons. The study suggested that additional research regarding the multisensory method and effective tools for teaching is necessary. 


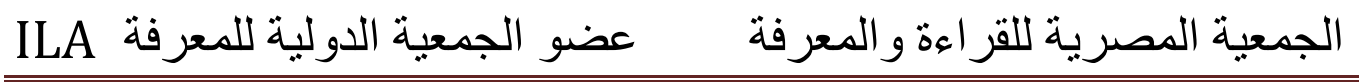

Based on the findings of the previous studies, the next generation of pre-service teachers needs to know how to make learning more relevant, interesting and meaningful to meet the varying needs of a more diverse population of students. They will be expected to design and implement authentic learning and assessment procedures, and model ways and skills that teachers can involve all students in varied, multisensory and interactive activities which will directly impact on them and help them have excellent instructional communication throughout performing immediacy skills.

\section{Methodology}

\subsection{The Subjects}

The present study targeted the fourth year prospective teachers of English Department- Elementary Education (38 students)- at the Faculty of Education, Port- Said University in the first semester of the academic year 2016 / 2017. Out of (38) EFL prospective teachers, (19) students were assigned to participate in the experimental group. All the participants were nearly of the same age and had the same schooling background.

\subsection{Hypotheses of the Study}

To answer the questions of the study, the researcher posited the following hypotheses:

1- There is a statistically significant difference between the mean ranks of the control group's scores and those of experimental group on the post assessment of their overall immediacy skills in favor of the experimental group.

2- There is a statistically significant difference between the mean ranks of the control group's scores and those of experimental group on the post assessment of their immediacy sub- skills in 


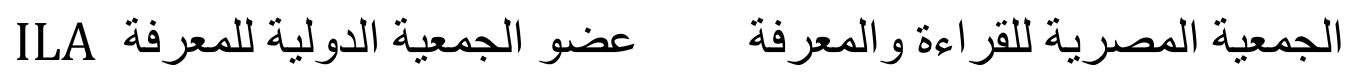

favor of the experimental group. The following sub-hypotheses are investigated:

a. There is a statistically significant difference between the mean ranks of the control group's scores and those of experimental group on the post assessment of their verbal immediacy skills in favor of the experimental group.

b. There is a statistically significant difference between the mean ranks of the control group's scores and those of experimental group on the post assessment of their nonverbal immediacy skills in favor of the experimental group.

3- There is a statistically significant difference between the mean ranks of the experimental group's scores on the pre and post assessment of their overall immediacy skills in favor of the latter.

4- There is a statistically significant difference between the mean ranks of the experimental group's scores on the pre and post assessment of their immediacy sub- skills in favor of the latter. The following sub-hypotheses are investigated:

a. There is a statistically significant difference between the mean ranks of the experimental group's scores on the pre and post assessment of their verbal immediacy skills in favor of the latter.

b. There is a statistically significant difference between the mean ranks of the experimental group's scores on the pre and post assessment of their nonverbal immediacy skills in favor of the latter. 


\subsection{Instruments of the Study}

The present study utilized the following quantitative and qualitative instruments:

\subsubsection{A Pre- Post Immediacy Skills Observation Checklist. (Quantitative Instrument)}

The researcher constructed an observation checklist to assess the prospective teachers' performances in immediacy skills before and after the treatment. The observation checklist is administered to both groups, control and experimental, before the treatment to make sure that studentteachers of both groups were at the same performance level, and hence the progress achieved by the experimental group could be attributed to the treatment they had been exposed to. The immediacy skills observation checklist consists of two main skills and a total of twenty sub-skills. The main skills are: (1) prospective teacher's verbal immediacy skills, and (2) prospective teacher's nonverbal immediacy skills. Each main skill contains ten sub- skills.

\section{Validity of the Checklist}

An immediacy skills questionnaire was designed in order to determine the immediacy skills required for EFL prospective teachers. Based on the results of the questionnaire, the immediacy skills observation checklist was constructed. The questionnaire was submitted to a panel of jury specialized in the field of EFL curriculum and instruction to determine: (1) the necessary skills to be included in the observation checklist, (2) if the skills were required or not required for fourth year EFL prospective teachers at the Faculty of Education, and (3) the degree of importance of each skill to be performed in the classrooms by EFL prospective teachers. The checklist in its final form contains the main skills and their sub-skills as approved by the jurors with the modifications they suggested. The agreement of the jury about the skills was considered as approval of the validity of the observation checklist. 


\section{ILA الجمعية المصرية للقراءة والمعرفة عضو الجمعية الدولية للمعرفة}

The intrinsic validity of the checklist was calculated by using the correlation coefficients between the value of each item in the checklist and the total value of the main skills. The correlation coefficients values of the checklist items to the total values of the main skills are statistically significant at (0.01) and (0.05) levels. This indicates the intrinsic validity of the checklist.

\section{Reliability of the Checklist}

In order to determine the reliability of the checklist, it was administered to (17) fourth- year prospective teachers of English department- general education at the Faculty of Education Port-Said University. The students were neither included in the experimental nor the control groups as their results were excluded. The reliability of the checklist was obtained through calculating the internal consistency of the checklist by using Cronbach's Alpha formula. The reliability coefficient was (0.913) verifying the reliability of the checklist. All the Cronbach's Alpha Coefficient values of the immediacy skills observation checklist items are less than the general Cronbach's Alpha Coefficient which referred to that the checklist's items are reliable.

\subsubsection{Evaluation and Self-Reflection Quizzes. (Qualitative Instruments)}

After each lab session, every prospective teacher had an evaluation and self-reflection quiz to answer eight questions included. Evaluation and self-reflection quizzes assessed the prospective teacher's knowledge and comprehension of each presented verbal/ nonverbal immediacy skill with its ten sub-skills. The evaluation and self-reflection quizzes also included the prospective teachers' reflection and impressions about the learned skill and the session in general. 


\subsubsection{Peer Assessment Checklists. (Qualitative Instruments)}

Peer assessment involves prospective teachers providing feedback to their peers on the quality of their performance (poor-average-good-very good-excellent) in the target skills. Each peer assessment checklist contains one main target skill with its ten sub-skills to be observed and assessed by the prospective teachers. After each lab session, the instructor asked the prospective teachers to try to practice the learned skill with its ten sub-skills in their weekly practicum then they were given the peer assessment checklists of the practiced skill to assess each other performance. After the performances have been assessed, the instructor further discussed with the prospective teachers what they have seen and what they thought makes a better performance of the skill in the next performance time. The prospective teachers helped each other to make sense of the gaps in their performance of the target skills. Also, prospective teachers receiving feedback from their peers got a wider range of ideas to promote and improve their classroom performance.

\subsubsection{Student-Teachers' Reflective Logs. (Qualitative Instruments)}

Student-teachers' reflective logs are personal records of their teaching performance experience. In each student-teacher's reflective log, the prospective teachers were asked to look at what they did most effectively of the target skill in the classroom, thinking about what they could improve in their performance, and if it worked well. The student-teachers observed their own performance in the target skill, evaluated it in light of the modeled performance indicators seen in the sessions, and used this evaluation to generate and monitor improvements in their own performance later. After each practical performance of the target skill in the practicum, the prospective teachers were given the student-teacher's reflective log of each skill to answer three included reflective questions individually then the logs were submitted to the instructor for feedback. 


\section{الجمعية المصرية للقراعة و المعرفة عضو الجمعية الدولية للمعرفة ILA}

\subsection{Treatment}

The treatment of this study is based on the multi- sensory teaching to develop EFL prospective teachers' immediacy skills. This treatment aims are twofold: (a) developing the selected immediacy skills of EFL prospective teachers at the Faculty of Education; and (b) giving fourth year EFL prospective teachers at the Faculty of Education the opportunity to be trained on using the multi- sensory teaching to develop their immediacy skills which are necessary and helpful for EFL prospective teachers' performance to succeed in the teaching and the interacting processes in the classroom.

The treatment consists of five sessions for EFL prospective teachers spread over five weeks. The prospective teachers were given one session ( 2 hours) weekly during which, the researcher introduced immediacy with its verbal and nonverbal sub-skills, and modeled their performance indicators to the experimental group student-teachers (each two sessions contained developing one main skill with its ten sub-skills then the prospective teachers practiced the skill with its sub-skills in their weekly practicum under the researcher's guided supervision). During the instruction, the researcher used the multisensory teaching (VAKT). At the last week of the five weeks sessions and practicum, the prospective teachers practiced the developed immediacy skills as a whole in the final practicum of the academic first semester 2016/ 2017.

The materials used in the instruction include handouts for verbal and nonverbal immediacy skills, blank worksheets, white board, power point presentations, and videos, the sessions of the proposed program followed certain steps which are listed below:

- Objectives: the goals expected to be achieved by the end of each session.

- Material: the teaching aids and tools used within the session (handouts, power point presentations, blank worksheets, videos, and the whiteboard) 
- Warm- up: using the brainstorming technique about the presented skill.

- Multisensory Teaching Strategies (VAKT): modeling and acting out the target skills and sub-skills verbally and nonverbally, reading aloud the handouts, watching videos and power point presentations, and writing worksheets.

- Evaluation and Self-Reflection Quiz: the instructor assessed the prospective teachers' comprehension and reflection of each presented skill.

- Peer Assessment: a checklist contained the performance sub-skills of each skill to be observed by their peers.

- Prospective Teacher's Reflective Log: the prospective teachers look at what they did in the classroom, thinking about why they did it, and thinking about if it worked well - it is a log of selfobservation and self-evaluation.

\section{Major Procedures Followed in Implementing the Treatment}

The researcher introduced the following procedures included within the sessions:

- Using the brainstorming technique in order to warm- up the prospective teachers before introducing each skill to them. The prospective teachers can use a blank worksheet to write their ideas.

- Using the multisensory teaching (VAKT) in order to introduce each skill with its performance sub-skills to the prospective teachers.

- Discussing the prospective teachers and providing them with an overview of verbal and nonverbal immediacy 


\section{الجمعية المصرية للقر اعة والمعرفة عضو الجمعية الدولية للمعرفة}

skills with their performance sub-skills in every two sessions.

- Modeling each skill with its performance sub-skills to the prospective teachers using the multisensory teaching strategies.

- Supporting the prospective teachers to work in large and small groups to answer the evaluation quizzes and implement the peer- assessment checklists and studentteachers' reflective logs in the practicum.

- Reviewing the prospective teachers' answers within the evaluation quizzes, peer-assessment checklists, and student-teachers' reflective logs with the whole participants and providing corrective feedback.

- Performing independently the verbal and nonverbal immediacy skills in the practicum to be assessed by the immediacy skills checklist.

\section{Evaluation Methods}

There were two methods of assessment used in this treatment:

- Formative Evaluation: it was an ongoing assessment process during the sessions. It aimed at assessing the prospective teachers' progress and performance in practicing immediacy skills during the sessions. This was achieved by giving the prospective teachers of the experimental group the evaluation and self-reflection quiz, peer- assessment checklist of each skill, and student- teacher's reflective $\log$ at the end of each session to be applied in their weekly practicum.

- Summative Evaluation: it was another method of assessment used at the end of the treatment in order to evaluate the effectiveness of the multisensory teaching approach in developing EFL prospective teachers' 


\section{Results and Discussion}

immediacy skills. This summative evaluation took the form of the post administration of the immediacy skills observation checklist on the control and experimental groups after implementing the sessions of treatment.

The results of the study are analyzed and presented in light of the study hypotheses:

\subsection{First Hypothesis}

There is a statistically significant difference between the mean ranks of the control group's scores and those of experimental group on the post assessment of their overall immediacy skills in favor of the experimental group.

In order to verify this hypothesis, Mann-Whitney Nonparametric Test for independent samples was conducted on both the post assessment scores of the experimental and control groups to determine the relative extent of change achieved by the experimental group after implementing the treatment.

Table1. Results of Mann-Whitney Test for the Experimental and Control Groups Post Assessment of Overall Immediacy Skills.

\begin{tabular}{|c|c|c|c|c|c|c|}
\hline Variable/ Skill & Groups & $\mathbf{N}$ & $\begin{array}{l}\text { Mean } \\
\text { Ranks }\end{array}$ & $\begin{array}{c}\text { Sum } \\
\text { of } \\
\text { Ranks }\end{array}$ & $\begin{array}{c}\text { U } \\
\text { Value }\end{array}$ & Significance \\
\hline \multirow{3}{*}{$\begin{array}{l}\text { Immediacy } \\
\text { Skills }\end{array}$} & Experimental & 19 & 29 & 551 & \multirow{3}{*}{5.3} & \multirow{3}{*}{$\begin{array}{c}\text { Significant } \\
0.01\end{array}$} \\
\hline & Control & 19 & 10 & 190 & & \\
\hline & Sum & 38 & - & - & & \\
\hline
\end{tabular}

Results in table (1) shows that there is a significant statistical difference between the mean ranks of the experimental and control groups' scores on the post-assessment of overall immediacy skills in favor 


\section{الجمعية المصرية للقر اعة والمعرفة عضو الجمعية الدولية للمعرفة ILA}

of the experimental group. This indicates that the experimental group scored higher on the overall immediacy skills post-assessment than the scores of the control group. The Mann-Whitney test results show that this difference is considered to be statistically significant at (0.01) level, as $u$ value is statistically significant at (0.01) level. The interpretation of this difference proves that the overall immediacy skills of the experimental group who implemented the treatment have been improved. This confirms the positive effect of the multisensory teaching approach on developing their overall immediacy skills. Therefore the first hypothesis of this study is verified.

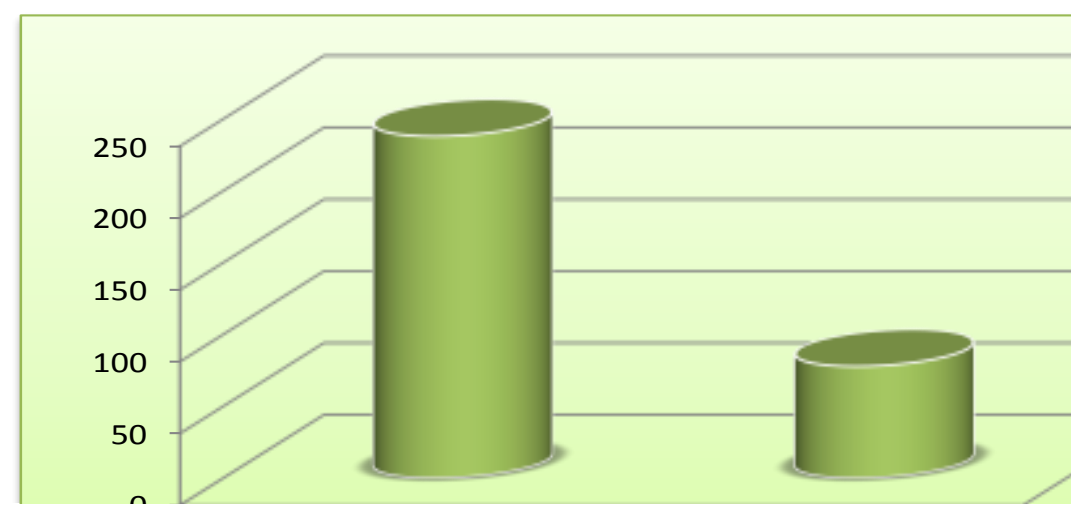

Figure2. The Experimental and Control Groups' Mean Scores on Post Immediacy Skills Assessment.

\subsection{Second Hypothesis}

There is a statistically significant difference between the mean ranks of the control group's scores and those of experimental group on the post assessment of their immediacy sub- skills in favor of the experimental group. The following sub-hypotheses are investigated:

a. There is a statistically significant difference between the mean ranks of the control group's scores and those of experimental group on the post assessment of their verbal immediacy skills in favor of the experimental group. 


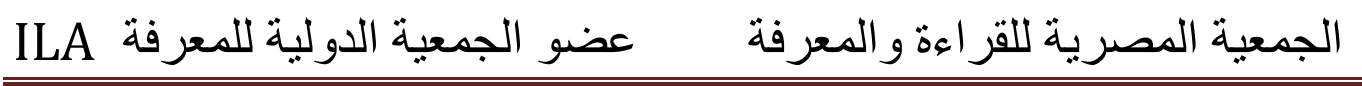

In order to verify this hypothesis, Mann-Whitney Nonparametric Test for independent samples was conducted on both the post assessment scores of the experimental and control groups to determine the relative extent of change achieved by the experimental group after implementing the treatment.

Table2. Results of Mann-Whitney Test for the Experimental and Control Groups Post Assessment of Verbal Immediacy Skills.

\begin{tabular}{|c|c|c|c|c|c|c|}
\hline $\begin{array}{c}\text { Variable/ } \\
\text { Skill }\end{array}$ & Groups & $\mathbf{N}$ & $\begin{array}{c}\text { Mean } \\
\text { Ranks }\end{array}$ & $\begin{array}{c}\text { Sum of } \\
\text { Ranks }\end{array}$ & $\begin{array}{c}\text { U } \\
\text { Value }\end{array}$ & Significance \\
\hline $\begin{array}{c}\text { Verbal } \\
\text { Immediacy } \\
\text { Skills }\end{array}$ & Experimental & 19 & 29 & 551 & \multirow{2}{*}{5.3} & \multirow{2}{*}{\begin{tabular}{c} 
Significant \\
\cline { 2 - 5 }
\end{tabular}} \\
\cline { 2 - 5 } & Control & 19 & 10 & 190 & -01 \\
\hline
\end{tabular}

Results in table (2) shows that there is a significant statistical difference between the mean ranks of the experimental and control groups' scores on the post-assessment of verbal immediacy skills in favor of the experimental group. This indicates that the experimental group scored higher on the verbal immediacy skills post-assessment than the scores of the control group. The Mann-Whitney test results show that this difference is considered to be statistically significant at (0.01) level, as $u$ value is statistically significant at (0.01) level. The interpretation of this difference proves that the verbal immediacy skills of the experimental group who implemented the treatment have been improved. This confirms the positive effect of the multisensory teaching approach on developing their verbal immediacy skills. Therefore the second hypothesis of this study is verified. 


\section{الجمعية المصرية للقر اعة و المعرفة عضو الجمعية الدولية للمعرفة ILA}

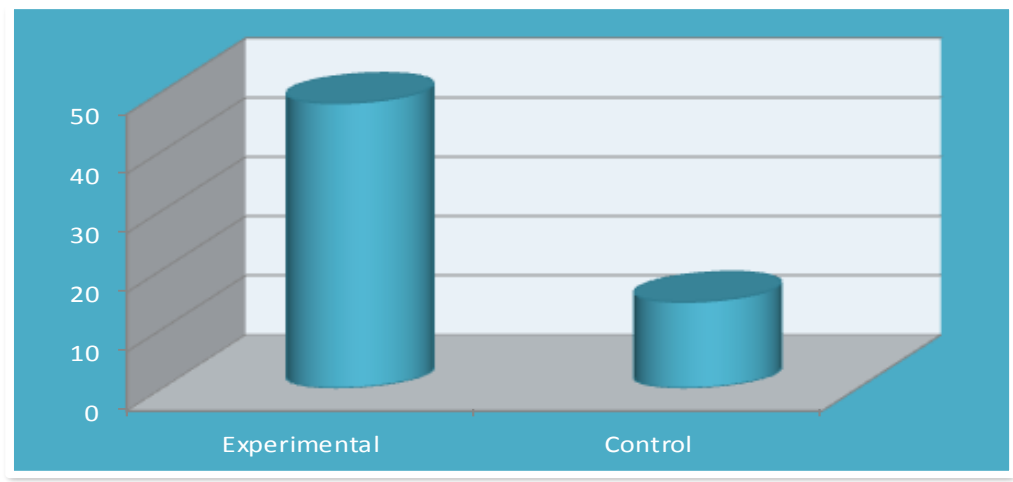

Figure3. The Experimental and Control Groups' Mean Scores on Post Verbal Immediacy Skills Assessment.

$b$. There is a statistically significant difference between the mean ranks of the control group's scores and those of experimental group on the post- assessment of their nonverbal immediacy skills in favor of the experimental group.

In order to verify this hypothesis, Mann-Whitney Nonparametric Test for independent samples was conducted on both the post assessment scores of the experimental and control groups to determine the relative extent of change achieved by the experimental group after implementing the treatment.

Table3. Results of Mann-Whitney Test for the Experimental and Control Groups Post Assessment of Nonverbal Immediacy Skills.

\begin{tabular}{|c|c|c|c|c|c|c|}
\hline $\begin{array}{l}\text { Variable/ } \\
\text { Skill }\end{array}$ & Groups & $\mathbf{N}$ & $\begin{array}{l}\text { Mean } \\
\text { Ranks }\end{array}$ & $\begin{array}{l}\text { Sum of } \\
\text { Ranks }\end{array}$ & $\begin{array}{c}\mathbf{U} \\
\text { Value }\end{array}$ & Significance \\
\hline \multirow{3}{*}{$\begin{array}{c}\text { Nonverbal } \\
\text { Immediacy } \\
\text { Skills }\end{array}$} & Experimental & 19 & 29 & 551 & \multirow{3}{*}{5.3} & \multirow{3}{*}{$\begin{array}{c}\text { Significant } \\
0.01\end{array}$} \\
\hline & Control & 19 & 10 & 190 & & \\
\hline & Sum & 38 & - & - & & \\
\hline
\end{tabular}




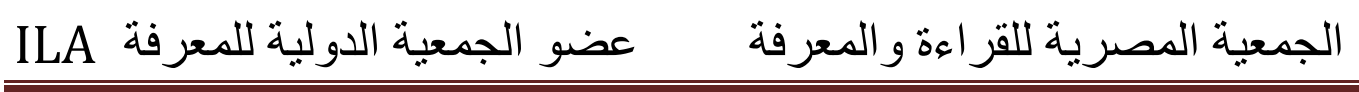

Results in table (3) shows that there is a significant statistical difference between the mean ranks of the experimental and control groups' scores on the post-assessment of nonverbal immediacy skills in favor of the experimental group. This indicates that the experimental group scored higher on the nonverbal immediacy skills post-assessment than the scores of the control group. The Mann-Whitney test results show that this difference is considered to be statistically significant at (0.01) level, as $u$ value is statistically significant at (0.01) level. The interpretation of this difference proves that the nonverbal immediacy skills of the experimental group who implemented the treatment have been improved. This confirms the positive effect of the multisensory teaching approach on developing their nonverbal immediacy skills. Therefore the second hypothesis of this study is verified.

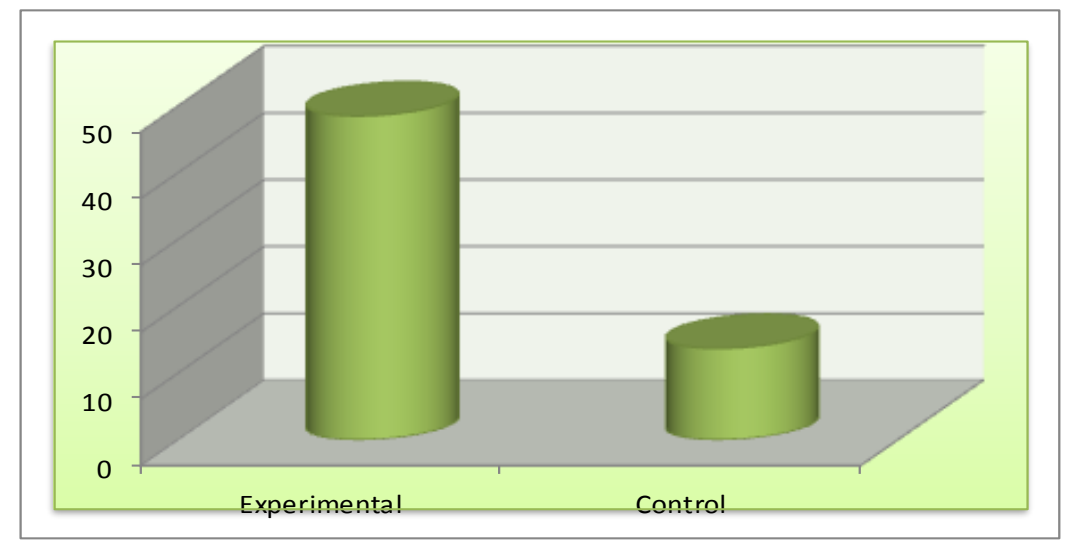

Figure4. The Experimental and Control Groups' Mean Scores on Post Nonverbal Immediacy Skills Assessment.

\subsection{Third Hypothesis}

There is a statistically significant difference between the mean ranks of the experimental group's scores on the pre and post assessment of their overall immediacy skills in favor of the latter. 
In order to verify this hypothesis, Wilcoxon Nonparametric Test for dependent samples was conducted on both the pre and post assessment scores of the experimental group to determine the relative extent of change achieved by the experimental group after implementing the treatment.

Table4. Results of Wilcoxon Test for the Experimental Group Pre and Post Assessment of Overall Immediacy Skills.

\begin{tabular}{|c|c|c|c|c|c|c|}
\hline Variable/ Skill & Ranks & $\mathbf{N}$ & $\begin{array}{c}\text { Mea } \\
\mathbf{n}\end{array}$ & $\begin{array}{c}\text { Sum } \\
\text { of } \\
\text { Rank } \\
\text { S }\end{array}$ & $\begin{array}{c}\mathbf{Z} \\
\text { Valu } \\
\mathbf{e}\end{array}$ & $\begin{array}{c}\text { Significan } \\
\text { ce }\end{array}$ \\
\hline \multirow{4}{*}{$\begin{array}{c}\text { Immediacy } \\
\text { Skills }\end{array}$} & $\begin{array}{l}\text { Negati } \\
\text { ve }\end{array}$ & $\mathbf{0}$ & $\mathbf{0}$ & $\mathbf{0}$ & \multirow{4}{*}{3.84} & \multirow{4}{*}{$\begin{array}{c}\underset{\mathbf{t}}{\text { Significan }} \\
\mathbf{0 . 0 1}\end{array}$} \\
\hline & $\begin{array}{c}\text { Positiv } \\
\text { e }\end{array}$ & 19 & 10 & 190 & & \\
\hline & Equals & $\mathbf{0}$ & - & - & & \\
\hline & Sum & 19 & - & - & & \\
\hline
\end{tabular}

Results in table (4) shows that there is a significant statistical difference between the mean ranks of pre and post overall immediacy skills assessment of the experimental group's scores in favor of post assessment scores. This indicates that the experimental group scored higher on the overall immediacy skills post assessment than the scores on the overall immediacy skills pre-assessment. The Wilcoxon test results show that this difference is considered to be statistically significant at (0.01) level, as $\mathrm{Z}$ value is significant at (0.01) level. The interpretation of this difference proves that the overall immediacy skills of the students who participated in the treatment have been improved. This confirms the positive effect of the multisensory teaching approach on developing their overall immediacy skills. Therefore the third hypothesis of this study is verified. 


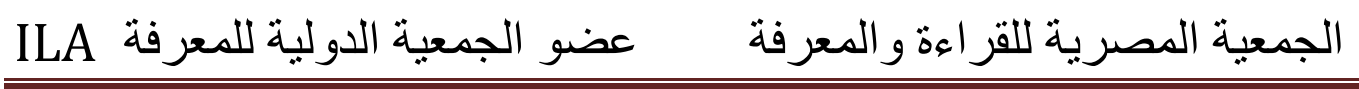

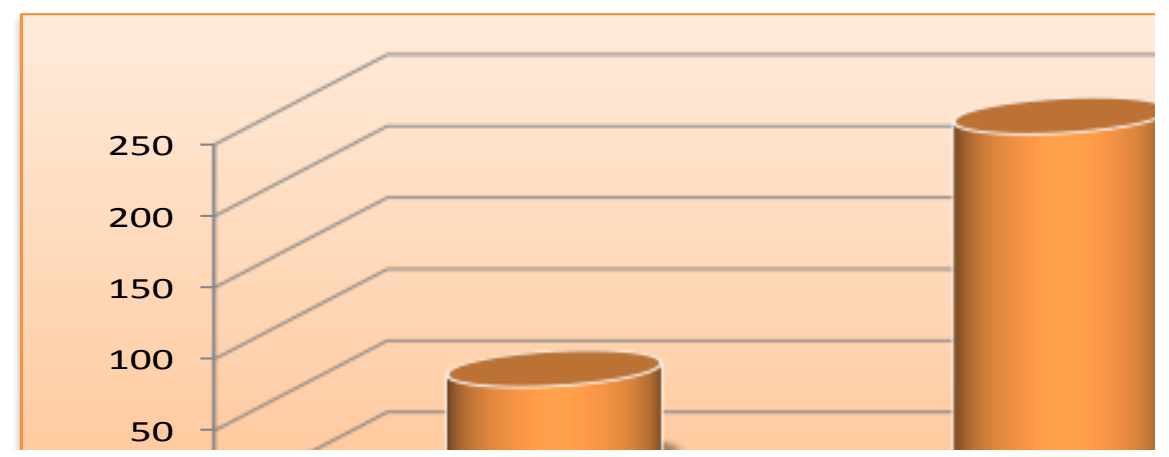

Figure5. The Experimental Group's Mean Scores on Pre- and Post- Immediacy Skills Assessment.

\subsection{Fourth Hypothesis}

There is a statistically significant difference between the mean ranks of the experimental group's scores on the pre and post assessment of their immediacy sub- skills in favor of the latter. The following subhypotheses are investigated:

a. There is a statistically significant difference between the mean ranks of the experimental group's scores on the pre and post assessment of their verbal immediacy skills in favor of the latter.

In order to verify this hypothesis, Wilcoxon Nonparametric Test for dependent samples was conducted on both the pre and post assessment scores of the experimental group to determine the relative extent of change achieved by the experimental group after implementing the treatment. 


\section{الجمعية المصرية للقراءة والمعرفة عضو الجمعية الدولية للمعرفة ILA}

Table5. Results of Wilcoxon Test for the Experimental Group Pre And Post Assessment of Verbal Immediacy Skills.

\begin{tabular}{|c|c|c|c|c|c|c|}
\hline $\begin{array}{c}\text { Variable/ } \\
\text { Skill }\end{array}$ & Ranks & $\mathbf{N}$ & $\begin{array}{c}\text { Mea } \\
\mathbf{n}\end{array}$ & $\begin{array}{l}\text { Sum of } \\
\text { Ranks }\end{array}$ & $\begin{array}{c}Z \\
\text { Value }\end{array}$ & $\underset{\text { ce }}{\text { Significan }}$ \\
\hline \multirow{5}{*}{$\begin{array}{l}\text { Verbal } \\
\text { Immedia } \\
\text { cy Skills }\end{array}$} & Negativ & 0 & 0 & 0 & \multirow{5}{*}{3.84} & \multirow{4}{*}{$\underset{t}{\text { Significan }}$} \\
\hline & e & & & & & \\
\hline & Positive & 19 & 10 & 190 & & \\
\hline & Equals & 0 & - & - & & \\
\hline & Sum & 19 & - & - & & 0.01 \\
\hline
\end{tabular}

Results in table (5) shows that there is a significant statistical difference between the mean ranks of pre and post verbal immediacy skills assessment of the experimental group's scores in favor of post assessment scores. This indicates that the experimental group scored higher on the verbal immediacy skills post assessment than the scores on the verbal immediacy skills pre-assessment. The Wilcoxon test results show that this difference is considered to be statistically significant at (0.01) level as $\mathrm{Z}$ value is significant at (0.05) level. The interpretation of this difference proves that the verbal immediacy skills of the students who participated in the treatment have been improved. This confirms the positive effect of the multisensory teaching approach on developing their verbal immediacy skills. Therefore the fourth hypothesis of this study is verified. 


\section{الجمعية المصرية للقر اعة و المعرفة عضو الجمعية الدولية للمعرفة ILA}

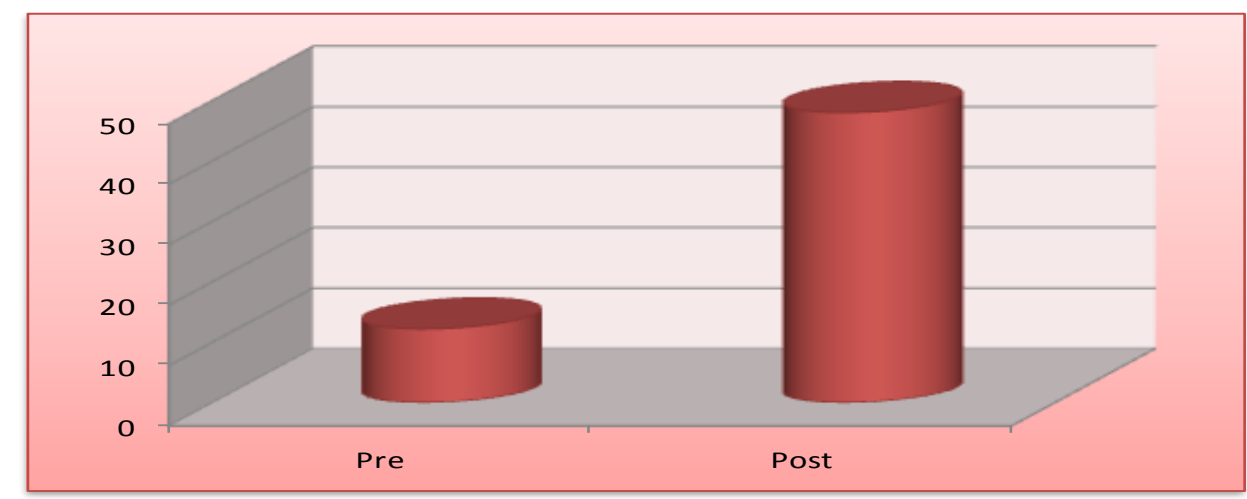

Figure6. The Experimental Group's Mean Scores on Pre- and PostVerbal Immediacy Skills Assessment.

$b$. There is a statistically significant difference between the mean ranks of the experimental group's scores on the pre and post assessment of their nonverbal immediacy skills in favor of the latter.

In order to verify this hypothesis, Wilcoxon Nonparametric Test for dependent samples was conducted on both the pre and post assessment scores of the experimental group to determine the relative extent of change achieved by the experimental group after implementing the treatment.

Table6. Results of Wilcoxon Test for the Experimental Group Pre and Post Assessment of Nonverbal Immediacy Skills.

\begin{tabular}{|c|c|c|c|c|c|c|}
\hline $\begin{array}{c}\text { Variable/ } \\
\text { Skill }\end{array}$ & Ranks & $\mathbf{N}$ & $\begin{array}{c}\text { Mea } \\
\text { n }\end{array}$ & $\begin{array}{l}\text { Sum of } \\
\text { Ranks }\end{array}$ & $\begin{array}{c}Z \\
\text { Value }\end{array}$ & $\underset{\text { ce }}{\text { Significan }}$ \\
\hline \multirow{5}{*}{$\begin{array}{l}\text { Nonverb } \\
\text { al } \\
\text { Immedia } \\
\text { cy Skills }\end{array}$} & Negativ & 0 & 0 & 0 & \multirow{5}{*}{3.84} & \multirow{5}{*}{$\underset{t}{\text { Significan }}$} \\
\hline & e & & & & & \\
\hline & Positive & 19 & 10 & 190 & & \\
\hline & Equals & 0 & - & - & & \\
\hline & Sum & 19 & - & - & & \\
\hline
\end{tabular}

广人 


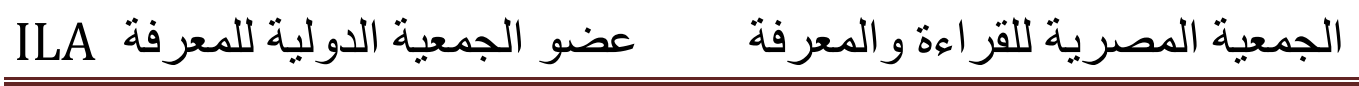

Results in table (6) shows that there is a significant statistical difference between the mean ranks of pre and post nonverbal immediacy skills assessment of the experimental group's scores in favor of post assessment scores. This indicates that the experimental group scored higher on the nonverbal immediacy skills post assessment than the scores on the nonverbal immediacy skills pre- assessment. The Wilcoxon test results show that this difference is considered to be statistically significant at (0.01) level, as $\mathrm{Z}$ value is significant at (0.01) level. The interpretation of this difference proves that the nonverbal immediacy skills of the students who participated in the treatment have been improved. This confirms the positive effect of the multisensory teaching approach on developing their nonverbal immediacy skills. Therefore the fourth hypothesis of this study is verified.

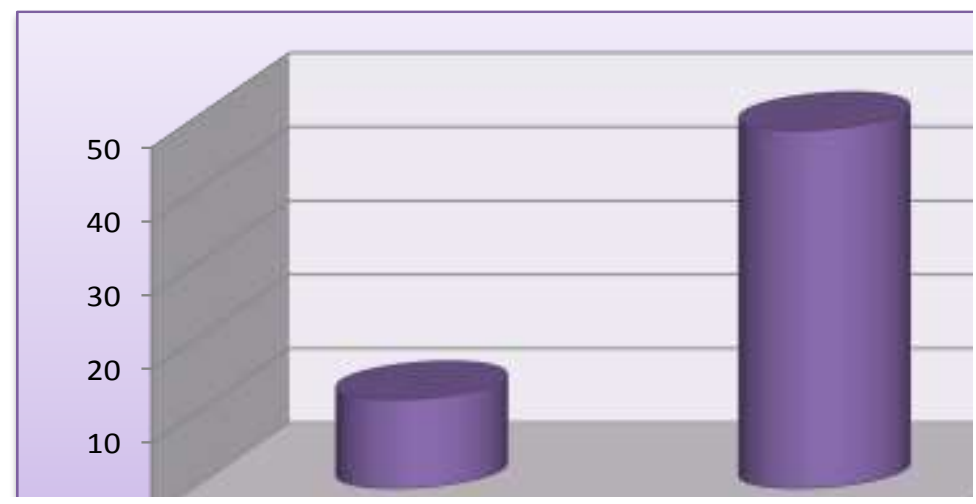

Figure7. The Experimental Group's Mean Scores on Pre- and PostNonverbal Immediacy Skills Assessment.

\subsection{Analyzing the Qualitative Results of the Study}

This section discusses the participants' notes, comprehension, impressions, responses, performance and reflection in the qualitative assessment instruments in terms of informal discussions, evaluation and self-reflection quizzes, peer-assessment checklists, and studentteachers reflective logs during implementing the immediacy skills in the treatment's lab- sessions and the practicum classrooms (23 
December Primary School and AL-Tannis Primary School at PortSaid City).

\section{Verbal Immediacy Skills}

In verbal immediacy skills sessions, during the informal discussion with the researcher, a prospective teacher said: "If the teacher enjoys teaching, this will reflect on his/her performance and the pupils will like him/her". Some prospective teachers agreed that: "Using humor in the classroom could attract the pupils' attention and motivate them"; "Students have fun and consequently feel happy and secure in the classroom". EFL prospective teachers recognized that it is very important to be close to their pupils in order to increase the interaction and consequently promote their cognitive, affective, and behavioral learning.

In their evaluation and self-reflection quiz responses after the lab-session, most of the prospective teachers mentioned: "The subskills of praising the student's work, using humor, and asking how students feel about the assignment and topics are the verbal immediacy skills we would like to practice most". EFL prospective teachers have reported that "the pupils, as a result of practicing verbal immediacy skills, would feel closeness and comfortable with the teacher". At the end of this theoretical session, the prospective teachers were very interested in practicing verbal immediacy skills in the next practicum.

During the practical session of verbal immediacy skills in the practicum, the researcher gave the prospective teachers the peer assessment checklists of verbal immediacy skills in order to assess their peers' performance in the classrooms. At the beginning of the practical session, most EFL prospective teachers mentioned: "We might face difficulty in implementing all the ten verbal immediacy skills in one period"; "I am not confident enough to perform the ten sub-skills". But the researcher/instructor tried to give them the 
confidence and support. She said "You can do well, I am sure! Even if you tried to implement at least five or six skills in one period, you would succeed". According to the peer assessment checklists; their performances were assessed to range from average to very good in performing most of verbal immediacy skills in the practicum.

In the student-teachers' reflective logs after the practicum, EFL prospective teachers stated that they have learned how to be verbal immediate teachers and that the verbal immediacy skills properly increased interaction in the classroom. They mentioned: "The subskills of calling the students with their first names, humoring, and providing timely feedback increased students' self-confidence and happiness". They revealed that "Using verbal immediacy skills helped their students not to be shy and were encouraged to participate in different activities, answer questions, speak and freely express themselves".

\section{Nonverbal Immediacy Skills}

In nonverbal immediacy skills sessions; during the informal discussion with the researcher, she referred that an immediate teacher means a more expressive teacher. EFL prospective teachers recognized the importance of nonverbal communication in the classroom and said: "Using nonverbal immediacy skills could increase the pupils' use of their senses that lead to more success in the learning process". Most of EFL prospective teachers liked moving inside the classroom and not to stand all the time at front of the classroom.

In the evaluation and self-reflection quiz after the lab-session, EFL prospective teachers referred to the sub-skill of maintaining eye contact with their students and how they could reflect what they feel throughout eye contact and facial expressions. They mentioned that the teacher should be active with calm and smiley face. Here are some of the EFL prospective teachers' actual writings: "Smile to 
express my happiness and upset to show my sadness or anger"; "Nonverbal immediacy is clearly simulated when a student speaks and the teacher listens attentively, nods head as a prompt for the student to continue his/her answers, thus, nonverbal immediacy is positively correlated with the students' willingness to speak and participate in the learning activities".

According to the peer assessment checklists during the practicum, their performances were assessed to range from good to excellent in most of the performance sub-skills. Most of them were assessed to be good and very good in using body language; using colors, media, clipart; nodding head when listening attentively to the pupils, and having a kind and smiley facial expression. They also were very good in using and matching the facial expressions for both positive and negative reinforcement, moving closer to pupils around the classroom, and maintaining eye contact while talking to the pupils.

In the student-teachers' reflective logs after the practicum, here are some of their reflections: "Using nonverbal immediacy skills perfectly affected classroom management and control"; "Nonverbal immediacy skills created a positive relationship and reduced the psychological distance between the teacher and students"; "I did not stay at one place in the classroom. I moved around, kept eye contact with my pupils and encouraged them to participate"; "I have to allow the pupils touch the teaching aids (realia) and even taste and smell it if possible!"; "Nonverbal immediacy skills created a supportive and encouraging classroom climate, as a nonverbal immediate teacher made the classroom full of warmth, safety, acceptance, and genuineness".

To sum up, with reference to the previously mentioned results and discussion of this study, it could be concluded that the multisensory teaching approach to develop immediacy skills helped the EFL prospective teachers to become more successful and 
interactive teachers in the classrooms. The multisensory teaching approach has proven to be effective in promoting EFL studentteachers' immediacy skills in particular and classroom/ instructional communication in general. Therefore, both the quantitative and qualitative findings revealed that the proposed treatment provided the EFL prospective teachers the opportunity to learn how to create and support a friendly, interactive, encouraging, and motivating learning environment in the classroom throughout implementing multisensory teaching approach and developing their verbal and nonverbal immediacy skills .

\section{Conclusion}

The present study was conducted to develop verbal and nonverbal immediacy skills of EFL prospective teachers throughout using multisensory teaching in the primary classrooms. Competent teachers should have certain instructional communication skills to facilitate and motivate their students' learning, as long as the conventional teacher preparation and training programs usually concentrate on the basic famous teaching skills (e.g. stating and achieving learning objectives, warming-up, using teaching strategies and aids, etc.). These skills almost advocate students' cognitive learning while ignore improving their affective and behavioral learning which mostly related to motivation and interaction in the learning process in the classroom. The researcher found that using multisensory teaching in the classroom would help developing instructional communication and immediacy between the EFL teacher and students. The researcher concentrated on verbal and nonverbal immediacy skills that were implemented by EFL fourth year prospective teachers in the classroom. McCroskey, Richmond, and McCroskey (2006) predicted that the instructional communication skills would become one of the most effective domains for teachers' preparation in the years to come for fostering students' involvement in learning process. However according to the 
researcher's best knowledge, there were neither studies concerning instructional communication nor immediacy skills in the Egyptian EFL educational research context and this suggests new directions for researchers and educators. Therefore, the main findings of the present study provide evidence for the effectiveness of a multisensory teaching approach in developing EFL prospective teachers' immediacy skills. The experimental group participants showed a significant improvement in the selected verbal and nonverbal immediacy skills after being trained by the treatment sessions. This revealed that the main findings of the present study could overcome cognition, interaction, learning motivation, and teacher-students relationship problems appeared during the teaching process in EFL classrooms, and reduce EFL prospective teachers' anxiety related to the teaching process. The present study indicates the importance of providing safe, comfortable, friendly, and supportive classroom atmosphere which proved to be influential in motivating and involving students in the learning process. The students feel welcomed, respected, and acknowledged in the classroom. Multisensory teaching has an influential effect on the students' enjoyment, satisfaction, and engagement in the learning process.

\section{References}

Akers, A. \& Johnson, A. (2006). Instructional Communication: An Applied context. Retrieved March 27, 2014, from http://www.uky.edu

Alwaqassi, S.A. (2017). The Use of Multisensory in Schools Today. (Master's Thesis, the Faculty of the School of Education, Indiana University). Retrieved March 8, 2018, from http://www. scholarworks.iu.edu

Asiri, A.A. (2013). The Impact of Instructor Immediacy on College Student Communication and Learning Outcomes in Saudi Arabia. (Doctoral Dissertation, 


\section{ILA الجمعية المصرية للقراءة والمعرفة عضو الجمعية الدولية للمعرفة}

College of Education, Victoria University, Australia). Retrieved March 7,2018, from http://www. vuir.vu.edu.au

Azmi, N. (2013). Multi-sensory Delivery in EFL Smart Classroom: Students' Perceptions of Benefits, Limitations and Challenges. Journal of Educational and Social Research, 3(1), 33 - 43

Baker, C.(2010). The Impact of Instructor Immediacy and Presence for on Line Student Affective Learning, Cognition, and Motivation. The Journal of Educators Online, 7(1), 1 - 30

Bedard, J.M. (2002). Effects of a Multi - Sensory Approach on Grade One Mathematics Achievement. Seminar: Trends, Issues, and Research in Childhood Education. Retrieved Feb 14, 2014, from http://www.touchmath.com

Bitter, G. (2011). Effects of Explicit, Multisensory, Structured Language Arts Instruction Compared to Conventional Reading Instruction. Technology Based Learning \& Research. Arizona State University, Retrieved April 6, 2014, from http://www.bitter.asu.edu

Brailey, L., \& Stowe, M. (2013). Multisensory Structured Language Education of Basic Language Skills: Another Way to Teach Word Study. Retrieved July 1, 2015, from http://www.nationalreadingpanel.org

Denny, R. (2001). Communicate to Win. United Kingdom: Kogan Page Limited.

El-Fatihi, M. (2006). The Role of Nonverbal Communication in Beginner's EFL Classrooms. Retrieved Nov 14, 2014, from http://www.ehc.ed.gov

Faylor, N., Beebe, S. Houser, M., \& Mottet, T. (2008). Perceived Differences in Instructional Communication Behaviors between Effective and Ineffective Corporate Trainers. A Publication of the Pacific and Asian Communication Association, Human Communication, 11(1), 145 156 


\section{الجمعية المصرية للقراءة والمعرفة عضو الجمعية الدولية للمعرفة ILA}

Falzon, R., Calleja, C., \& Muscat, C. (2011). Structured Multisensory Techniques in Reading and Learning Patterns - Some Considerations. (A Research Study, Faculty of Education, University of Malta). Retrieved Jan 4, 2014, from http://www.pedagogia.fcep.urv.cat

Ginsberg, S.M. (2004). The Role of Classroom Communication in Collage Faculty Transparency. (Doctoral Dissertation, Eastern Michigan University). Available from ProQuest Dissertation and Theses Database (UMI NO. 3158530).

Guerrero, A.N. (2017). Exploring the Relationship between Immediacy Behaviors and Student Motivation in Engineering Classrooms: Immediacy as a Cause of Motivation. (Master Thesis, South Dakota State University). Retrieved July 25,2017, from http://www.openprairie,sdstate.edu

Henry, M.K. (2008). Multisensory Structured Language Teaching. International Dyslexia Association. Retrieved Jan 4, 2014, from http://www.dyslexiasd.org

Homer, V. (2007). An Investigation into the Effectiveness of Multisensory Environments in Developing Early Communication Skills in Children with Profound and Multiple Learning Difficulties. (Master's Thesis, Department of Human Communication Science, University College London). Available from ProQuest Dissertation and Theses Database. (UMI NO.U594B12)

Hughes, G.K. (2014). The Effect of Mediated Immediacy upon State Motivation and Cognitive Learning in an on Line Lesson. (Doctoral Dissertation, Collage of Communication and Information, University of Kentucky). Retrieved from http://www.uknowledge.uky.edu

Hsu, L. (2010). The Impact of Perceived Teachers' Nonverbal Immediacy on Students' Motivation for Learning English. Asian EFL Journal, 12 (4), 1-17. Retrieved Dec 3, 2014, from http://www. asian-efljournal.com 


\section{الجمعية المصرية للقر اءة والمعرفة عضو الجمعية الدولية للمعرفة ILA}

Jasmine, J. \& Connolly, M. (2015). The Use of Multisensory Approaches during Center Time, through Visual, Auditory, and Kinesthetic-Tactile Activities to Enhance Spelling Accuracy of Second Grade Students. Journal of Education \& Social Policy, 2(1), 12 - 19

Johnson, A.D., \& McCroskey, J.C. (2004). Machiavellianism, Biological Sex, and Communication Orientations. Human Communication, 2(13), $57-67$

Kerssen- Griep, J.D. (1997). Teacher Communication and Student Motivation to Learn: Competence as Classroom Framework. (Doctoral Dissertation, University of Washington). Available from A Beil \& Howell Information Company (UMI NO. 9819260)

MacGregor, I.M. (2001). Toward Mutual Responsibility in Classroom Communication: Exploring College Student Classroom Communication. (Doctoral Dissertation, College of the Liberal Arts, the Graduate School, the Pennsylvania State University). Available from ProQuest Dissertation and Theses Database. (UMI NO. 3036076)

Malik, S. Kh.(2012).Prospective Teachers' Awareness about Interpersonal Skills- A Comparative Study. Interdisciplinary Journal of Contemporary Research in Business, 3(11), 514-522

Mathis, R.S. (2006). A Review of Literature Examining the Application of Instructional Communication to the Training and Development Profession. Texas A\&M University, pp. 288- 294, Retrieved Nov14, 2014, from http://www.files-eric.ed.gov

McCroskey, J.C., Valencic, K.M., \& Richmond, V.P (2004). Toward a General Model of Instruction Communication. Communication Quarterly, 52(3), 197 - 210

McCroskey, J.C., Richmond, V.P., \&McCroskey, L.L. (2006). An Introduction to Communication in the classroom: the Role of Communication in Teaching and Training. Boston, MA: Allyn \& Bacon 


\section{الجمعية المصرية للقراءة والمعرفة عضو الجمعية الدولية للمعرفة ILA}

McCroskey, L. L., Teven, J. J., Minielli, M. C., \& McCroskey, V. P. (2014). James C. McCroskey's Instructional Communication Legacy: Collaborations, Mentorships, Teachers, and Students. Communication Education, 63(4), 283-307.

doi:10.1080/03634523.2014.911929

Moustafa, B.M. (1999). Multisensory Approaches and Learning Styles Theory in the Elementary School: Summary of Reference Papers. The Educational Resources Information Center (Eric). Retrieved Feb 14, 2014, from http://www.eric.org

Mottet, T.P., Richmond, V.P., \& McCroskey, J.C. (2006). The Hand book of Instructional Communication: Rhetorical and Relational Perspectives. Boston, MA: Allyn \& Bacon

Mottet,T., Garza,R., Beebe,S., Houser,M., Jurrells, S., \& Furler, L. (2008). Instructional Communication Predictors of Ninth-Grade Students' Affective Learning in Math and Science. Communication Education, $57(3), 333-355$

Myers, S.A. (2010). Instructional Communication: The Emergence of a Field Retrieved Mar 5, 2014, from http://www.uk.sagepub.com

Ozmen, K.S. (2011). Perception of Nonverbal Immediacy and Effective Teaching among Student Teachers: Study across Cultural Extremes. International on Line Journal of Educational Sciences, 3(3), $865-881$

Price, C. (2010). Multisensory Learning Theory: Active and Multisensory Learning. Retrieved March 12, 2014, from http://www.studymode.com

Richmond, V.P., Lane, D.R., \& McCroskey, J.C. (2006). Teacher Immediacy and the Teacher - Student Relationship. In Mottet, T.P., Richmond V.P., \& McCroskey, J.C., Handbook of Instructional 
Communication: Rhetorical and Relational Perspectives (pp. 167 - 194). Boston: Allyn \& Bacon.

Rains, J., Kelly, C., \& Durham, R. (2008). The Evolution of the Importance of Multisensory Teaching Techniques in Elementary Mathematics: Theory and Practice. Journal of Theory and Practice in Education, 4(2), 239 - 252

Saechou, T. (2005). Verbal and Nonverbal Immediacy: Sex Differences and International Teaching Assistants. (Doctoral Dissertation, Agricultural and Mechanical College, Louisiana State University). Retrieved Dec 3, 2014, from http://www. digitalcommons.lsu.edu

Scheffel, D.L., Shaw, J.C, \& Shaw, R. (2008). The Efficacy of a Supplementary Multisensory Reading Program for First - Grade Students. Retrieved July 14, 2015, from http://www.ortongillingham.org

Shu-Fang, N., \& Adust, R. (2008). Examining Teacher Verbal Immediacy and Sense of Classroom Community in on Line Classes. International JL. On E-learning, 7(3), 477 - 498

Spinelli, C. (1998). Teacher Education Reform: Promoting Interactive Teaching Strategies and Authentic Assessment for Instructing an Increasing Diverse Population of Students. Educational Leadership and Special Education Department, Monmouth University. Retrieved Feb 14, 2014, from http://www.eric.org

Stoffers, M. (2011). Using a Multisensory Teaching Approach to Impact Learning and Community in a Second Grade Classroom. (Master's Thesis, College of Education. Rowan University). Retrieved Jan 4, 2014, from http://www. rdw.rowan.edu

Tabasco, D. (2007). Investigation of Relationships among Teachers' Immediacy and Creativity, and Students' Perceived Cognitive Learning. (Doctoral Dissertation, Drexel University). Retrieved Jan 25, 2015, from http://www. idea.library.drexel.edu 


\section{الجمعية المصرية للقراءة والمعرفة عضو الجمعية الدولية للمعرفة ILA}

Valencic, K.M, McCroskey, J.C., \& Richmond, V.P. (2005). The Relationship between Teachers' Temperament and Students' Perceptions of Teacher Communication Behavior. Retrieved Jan 9, 2014, from http://www.jamescmccroskey.com

Velez, J. \& Cano, J. (2008). The Relationship between Teacher Immediacy and Student Motivation. Journal of Agricultural Education, 49(3), $76-86$

Winters, F.L. (2014). Faculty Communication in the Undergraduate College Classroom: A Student Perspective. (Doctoral Dissertation, Faculty of Drexel University). Available from ProQuest Dissertation and Theses Database, (UMI NO. 3638326)

Witt, P.L., Wheeless, L.R., \& Allen, M.A. (2004). A Meta Analytical Review of the Relationship between Teacher Immediacy and Student Learning. Communication Monographs, 71, $184-207$

Wrench, J.S., Richmond, V.P. \& Gorhann, J. (2009). Communication, Affect and Learning in the Classroom. 3rd Edition, California, USA: Tapestry Press. (ISBN: 1-56888-548-2)

Wrighton, Ch.A. (2010). Determining the Effectiveness of a Multisensory Approach to Teach the Alphabet and Phonemic Awareness Mastery in Kindergarten Children. (Doctoral Dissertation, Faculty of Argosy University Campus). Retrieved Jan 4, 2014, from http://www. safarilearning.com 